\title{
Role of Silicon in the Microstructural Development and Properties of Ti-15Nb-xSi Alloys for Biomedical Applications
}

\author{
Andrea Macleybiane Gois Tavares ${ }^{a}$, Edvaldo Alves de Souza ${ }^{b}$, Marcio Sangali Cristino da Silva ${ }^{c}$, \\ Gusttavo Reis Leite Matos', Wilton Walter Batista ${ }^{d}$ (D), Sandra Andreia Stwart de Araujo Souza ${ }^{d *}$ (D) \\ anstituto Federal de Alagoas, 57200-000, Penedo, AL, Brasil \\ ${ }^{b}$ Universidade Federal de Sergipe, Departamento de Física, 49100-000, São Cristóvão, SE, Brasil \\ ${ }^{c}$ Universidade Estadual de Campinas, Faculdade de Engenharia Mecânica, 13083-860, \\ Campinas, SP, Brasil \\ ${ }^{d}$ Universidade Federal de Sergipe, Departamento de Ciência e Engenharia de Materiais, 49100-000, \\ São Cristóvão, SE, Brasil
}

Received: September 15, 2020; Revised: January 07, 2021; Accepted: February 16, 2021

\begin{abstract}
Ti-Nb alloys are attractive for biomedical implants and the addition of Si can lead to an improved set of properties. This study investigates the effect on the microstructures and properties of solutiontreated Ti-15Nb-xSi alloys followed by furnace cooling (FC), and water quenching (WQ). Based on the results, Si acts as a $\beta$-stabilizing element by increasing the $\beta$ volume fraction from $13 \%-36 \%$ in FC samples to a range from $0 \%-0.55 \% \mathrm{Si}$. The elastic modulus decreased under both conditions and reached approximately $63 \mathrm{GPa}$ in WQ samples with $0.35 \%$ Si due to an increased $\alpha$ " unit cell volume. On the other hand, hardness increased with increased Si content under FC and WQ conditions to a maximum of $313 \mathrm{HV}$ in the WQ sample containing $0.55 \% \mathrm{Si}$.
\end{abstract}

Keywords: Ti alloys, biomaterial, Vickers hardness, elastic modulus.

\section{Introduction}

$\beta$-Ti alloys are the most promising candidates for biomedical implants ${ }^{1}$. Their compositions are developed using non-toxic elements (e.g., Nb, Mo, Zr, Ta, Fe, Sn and $\mathrm{Si}$ ) to reach low elastic moduli ${ }^{1-3}$, and in that respect, $\mathrm{Ti}-\mathrm{Nb}$ alloys attract a good deal of interest ${ }^{4-8}$. Moreover, this alloying element has excellent biocompatibility in vivo ${ }^{9}$ and is capable of significantly increasing the mechanical resistance of $\mathrm{Ti}^{8}$.

Biomaterials with low elastic moduli are essential for shielding stress reduction, which could lead to early implant rejection ${ }^{10}$. The elastic moduli in Ti-Nb alloys changes with $\mathrm{Nb}$ concentration in the form of a W-shaped curve with two minimums at approximately $15 \mathrm{wt} . \%$ and $42 \mathrm{wt} . \%{ }^{11}$, and these compositions are an ongoing focus of research ${ }^{12-15}$. Accordingly, Ti- $15 \mathrm{Nb}$ is more favorable than the Ti- $42 \mathrm{Nb}$ alloy due to its lower $\mathrm{Nb}$ content, which could potentially reduce manufacturing $\operatorname{costs}^{16}$, and its lower density. The Ti-15Nb alloy also exhibits the shape memory effect in martensitic condition ${ }^{17}$ and may have similar properties to other titanium alloys with higher concentrations of $\beta$-stabilizers in terms of deformability ${ }^{18}$ and elastic modulus ${ }^{17}$. E is approximately $95 \mathrm{GPa}$ when $\alpha$ and $\beta$ phases are formed with slow cooling ${ }^{19}$ and 59-72 GPa with rapid cooling, due to its martensitic structure $^{17,18}$. The latter condition is more attractive and corresponds to the curve profile described above.

Other alloying elements could be added to the $\mathrm{Ti}-15 \mathrm{Nb}$ alloy to improve its properties. Elements such as $\mathrm{Zr}, \mathrm{Sn}, \mathrm{Hf}$, $\mathrm{Fe}, \mathrm{Mo}, \mathrm{Si}$, and $\mathrm{Ta}$ have previously been added to $\mathrm{Ti}-\mathrm{Nb}$

*e-mail: sasouza.sandra@gmail.com alloys with this goal ${ }^{20-23}$; however, these studies focused on high $\mathrm{Nb}$ concentrations. The addition of $\mathrm{Si}$ has resulted in several advantages in these alloys, including a decrease in the elastic modulus by helping to suppress the $\omega$ phase in the $\beta$-matrix ${ }^{24}$, and increase in the mechanical resistance due to grain refinement ${ }^{25}$, and improved resistance to corrosion due to $\mathrm{SiO}_{2}$ formation and its action as a dopant on $\mathrm{TiO}_{2}$, which improves the resistive properties of the oxide layer $^{26}$. However, there is limited understanding about the influence of $\mathrm{Si}$ on phases and properties in relatively low $\mathrm{Nb}$ concentrations and there is no information in the literature about $\mathrm{Ti}-\mathrm{Nb}-\mathrm{Si}$ alloys at $15 \% \mathrm{Nb}$ concentration. Therefore, these results contribute to a better understanding of the role of $\mathrm{Si}$ in this system. Because these alloys are intended for the manufacture of implants, it is noteworthy that $\mathrm{Si}$ is found in relatively high concentrations in active osteoblasts, which are essential for bone extracellular matrix formation. This feature makes Si potentially capable of influencing the cell response at the bone-implant interface ${ }^{27}$. Consequently, this study investigated the effect on the microstructures, elastic moduli and hardness of solution-treated Ti-15Nb-xSi alloys $(\mathrm{x}=0 ; 0.15 ; 0.35 ; 0.55)$ to $\mathrm{FC}$ and WQ.

\section{Experimental Procedure}

Ti-15Nb-xSi alloys $(\mathrm{x}=0 ; 0.15 ; 0.35 ; 0.55)($ wt. \%) were melted in an arc furnace (Analog Instrumentation and Control, model AN9270) with a tungsten electrode under an argon atmosphere using a water-cooled copper 
hearth. The purity degree of starting elements $\mathrm{Ti}, \mathrm{Nb}$, and Si was $99.84 \%, 99.99 \%$, and $99.9999 \%$, respectively. A homogenizing treatment was conducted at $1000{ }^{\circ} \mathrm{C}$ for $8 \mathrm{~h}$, followed by hot rolling at $1000{ }^{\circ} \mathrm{C}$ to get $4-\mathrm{mm}$ thick plates. The alloys were mechanically cleaned and cut into samples of $25 \times 20 \times 3 \mathrm{~mm}$. Finally, samples were heated at $1000^{\circ} \mathrm{C}$ for $1 \mathrm{~h}$ and cooled under two different conditions, namely $\mathrm{FC}$ and WQ. The interstitial (oxygen and nitrogen) contents of the FC samples were measured using LECO 400 equipment.

All samples were mounted and ground with different $\mathrm{SiC}$ grits $(220-1,500)$ and polished with $6-3 \mu \mathrm{m}$ diamond paste and a $1 \mu \mathrm{m}$ alumina suspension. Chemical etching consisted of $6 \mathrm{~mL} \mathrm{HNO}_{3}, 3 \mathrm{ml} \mathrm{HF}$, and $91 \mathrm{ml} \mathrm{H}_{2} \mathrm{O}$. Samples were analyzed by optical microscopy (OM) (Carl ZEISS Axio SCOPEA.1) and scanning electron microscopy (SEM) (JEOL JCM - 5700). Energy dispersive X-ray spectroscopy (EDS) was used to map $\mathrm{Si}$ distribution and to determine the $\mathrm{Ti}, \mathrm{Nb}$, and $\mathrm{Si}$ composition of the polished samples. The mean grain size of each sample under FC and WQ conditions was measured using the ImageJ 1.46r program. XRD patterns were obtained using Rigaku DMAX100 equipment $(40 \mathrm{kV}, 30 \mathrm{~mA})$ with monochromatic $\mathrm{CuK \alpha} 1$ radiation, at angular range from $37^{\circ}-80^{\circ}(2 \theta)$ in $0.02^{\circ}$ step at counting time of $2 \mathrm{~s} / \mathrm{step}$. Rietveld's refinement was performed using the General Structure Analysis System II (GSAS-II) ${ }^{28}$ to determine the structural parameters and volume fractions of the phases.

Elastic moduli were measured by the ultrasonic method using a pulse generator/receiver Panametrics NDT Model $5072 \mathrm{PR}$, connected to piezoelectric transducers of $5 \mathrm{MHz}$ which were in contact with the samples via coupling gel. The values reported were the mean of three measurements. The Vickers hardness of all samples was measured in a Future Tech FV-700 machine by applying a $2 \mathrm{~kg}$ load for $15 \mathrm{~s}$. The reported hardness of each sample corresponded to mean value of 5 times the indentation.

\section{Results and Discussion}

\subsection{Microstructures}

The interstitial contents of Ti-15Nb-xSi samples that were heat-treated above $\beta$-transus at $1000^{\circ} \mathrm{C}$ for $1 \mathrm{~h}$ followed by FC are shown in Table 1 . The oxygen and nitrogen contents were in the range of $0.207 \pm 0.013 \mathrm{wt} . \%$ to $0.261 \pm 0.019 \mathrm{wt} . \%$, and $0.0017 \pm 0.0000 \mathrm{wt} . \%$ to $0.0069 \pm 0.0004 \mathrm{wt} . \%$, respectively. These results are consistent with the ASTM B977-19 standard ${ }^{29}$. Figure 1 presents SEM micrographs of the samples and shows $\alpha$ plates formed from prior $\beta$ grains. Small amounts of $\alpha$ phase, represented by irregular morphology, were only observed in samples with $\mathrm{Si}$ as shown in the optical micrographs in the upper right of Figure 1b-d. FC samples show coarse grains

Table 1. Interstitial contents of furnace-cooled Ti-15Nb-xSi samples.

\begin{tabular}{lcc}
\hline \multirow{2}{*}{$\begin{array}{c}\text { Nominal content } \\
\text { (wt.\%) }\end{array}$} & \multicolumn{2}{c}{ Interstitial contents (wt.\%) } \\
\cline { 2 - 3 } Ti-15Nb & $\mathrm{O}$ & $\mathrm{N}$ \\
\hline Ti-15Nb-0.15Si & $0.260 \pm 0.003$ & $0.0069 \pm 0.0004$ \\
\hline Ti-15Nb-0.35Si & $0.207 \pm 0.013$ & $0.0038 \pm 0.0021$ \\
\hline Ti-15Nb-0.55Si & $0.220 \pm 0.019$ & $0.0043 \pm 0.0007$ \\
\hline
\end{tabular}

with mean sizes of $1001 \pm 331,788 \pm 189,497 \pm 158$, and $432 \pm 109 \mu \mathrm{m}$ for Si concentrations of $0,0.15,0.35$, and 0.55 , respectively. Despite the wide range of these values as illustrated by the high standard deviations, the increase in Si content resulted in grain refinement, particularly in $0.35 \% \mathrm{Si}$. The literature notes that grain refinement caused by $\mathrm{Si}$ addition is due to the rejection of this alloying element as solidification begins, which provides a constitutional undercooling capable of activating adjacent nuclei resulting in a smaller grain size $\mathrm{e}^{30,31}$. Therefore, the consequence of a higher Si content is higher constitutional undercooling and, in turn, the activation of a larger number of adjacent nuclei.

Studies by Hon et al. ${ }^{19}$ show that a Ti-Nb alloy with $15 \%$ $\mathrm{Nb}$ contains both $\alpha$ and $\beta$ phases, but the $\alpha$ is prevalent. The XRD patterns of all samples under FC conditions confirm the presence of both phases (Figure 2). An in-depth analysis of the effect of Si on the hep ( $\alpha$-Ti) and bcc ( $\beta$-Ti) structures was conducted using the Rietveld method. Refinings, in the current study, were obtained from the XRD patterns of solid samples and some refinement indicators are shown in Figure 2 and the difference between observed and calculated patterns is represented by a gray line close to the abscissa axis. Variations in the structural parameters of $\alpha$ and $\beta$, and their volume fractions as a function of Si concentration, are shown in Figure 3.

Figure 3 a shows that samples with $0.15 \%$ and $0.35 \%$ Si recorded increased $a_{\alpha}$ and $c_{\alpha}$ lattice parameters. These increases were significantly higher in $a_{\alpha}$ at $0.15 \% \mathrm{Si}$ and in $c_{\alpha}$ at $0.35 \% \mathrm{Si}$, which reflects their increased unit cell volumes (Figure 3c), with the exception of $0.55 \% \mathrm{Si}$, which was slightly lower due to a decreased $c_{\alpha}$. Parameters of $a_{\beta}$ have a profile similar to that of $c_{\alpha}$, which increased the $\beta$ unit cell volume to $0.35 \% \mathrm{Si}$, as shown in Figure $3 \mathrm{c}$. The reduced $a_{\beta}$ value observed at $0.55 \% \mathrm{Si}$ is consistent with the study by Kim et al. ${ }^{24}$, who assessed the $\beta$ lattice parameters at $\mathrm{Si}$ concentrations ranging from $0.5 \%$ to 1.5 at. $\%$ ( 0.3 to 0.9 wt. $\%)$ in an alloy with 26 at. $\% \mathrm{Nb}(40.5 \mathrm{wt} . \% \mathrm{Nb})$. The above authors observed that $a_{\beta}$ decreased as Si content increased, and that the reduction followed a non-linear profile. It is also noteworthy that $\mathrm{Si}$ addition generated the same effect on the volume of $\alpha$ - and $\beta$-phase unit cells. However, the effect was stronger on $\beta$, notably at $0.35 \%$ and $0.55 \% \mathrm{Si}$, and this is coherent with the role of $\mathrm{Si}$ as a $\beta$-stabilizing element in Ti alloys ${ }^{24,25}$. According to Barriobero-Vila et al..$^{32}$, element partitioning in the alloy between $\alpha$ and $\beta$ enhances their respective stabilizing elements, i.e., the $\beta$ phase is richer in Si than $\alpha$. For higher Nb concentrations, the most significant contribution of $\mathrm{Si}$ in terms of the phases formed, is its ability to prevent the occurrence of $\omega$, which normally causes the weakening of alloys ${ }^{33}$. In furnace-cooled Ti-Nb alloys, $\omega$ precipitates are found in the $\beta$ matrix in the range of $26-35 \% \mathrm{Nb}^{19,33}$

$\mathrm{Si}$ addition to furnace-cooled $\mathrm{Ti}-15 \mathrm{Nb}$ samples also increased the $\beta$ volume fraction (Figure $3 \mathrm{~d}$ ). This reached 13 vol. $\%$ in the $\mathrm{Ti}-15 \mathrm{Nb}$ sample and increased to $17.7 \mathrm{vol} . \%$ at $0.15 \%$ Si. Alloys containing $0.35 \%$ and $0.55 \%$ Si showed 31 vol. $\%$ and 36 vol. $\% \beta$, respectively. Thus, this finding, once again, corroborated the $\beta$-stabilizer effect of $\mathrm{Si}$ and highlighted that the addition of $0.35 \%$ Si more effectively 

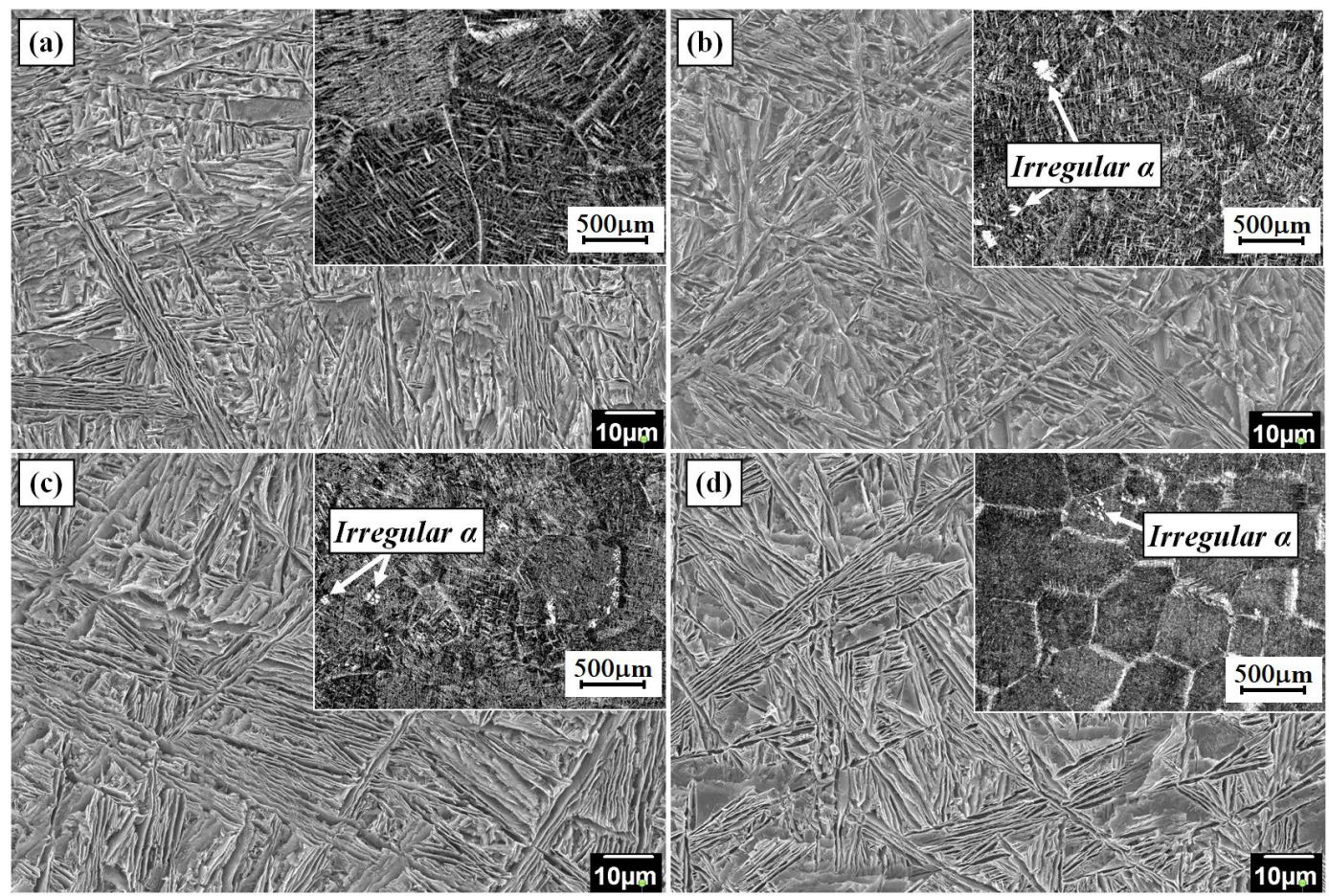

Figure 1. SEM micrographs of furnace-cooled samples: (a) Ti-15Nb, (b) Ti-15Nb-0.15Si, (c) Ti-15Nb-0.35Si, (d) Ti-15Nb-0.55Si. Inserts (a-d) present OM micrographs under lower magnifications.
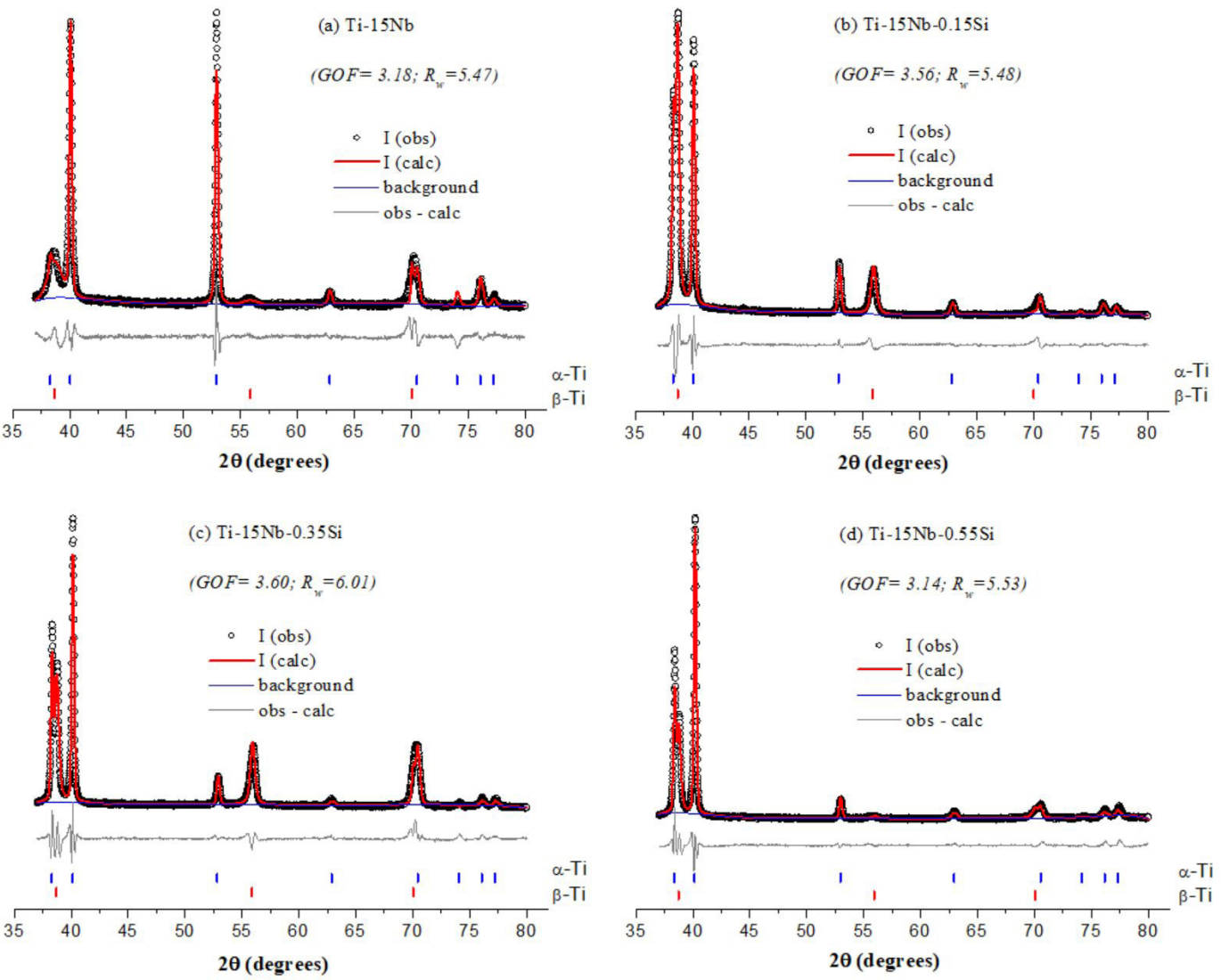

Figure 2. Observed (open circles) and calculated (solid red line) XRD patterns of FC Ti-15Nb-xSi samples. The difference (solid grey line) is shown at the bottom of the image and Bragg reflections are indicated by vertical marks. 

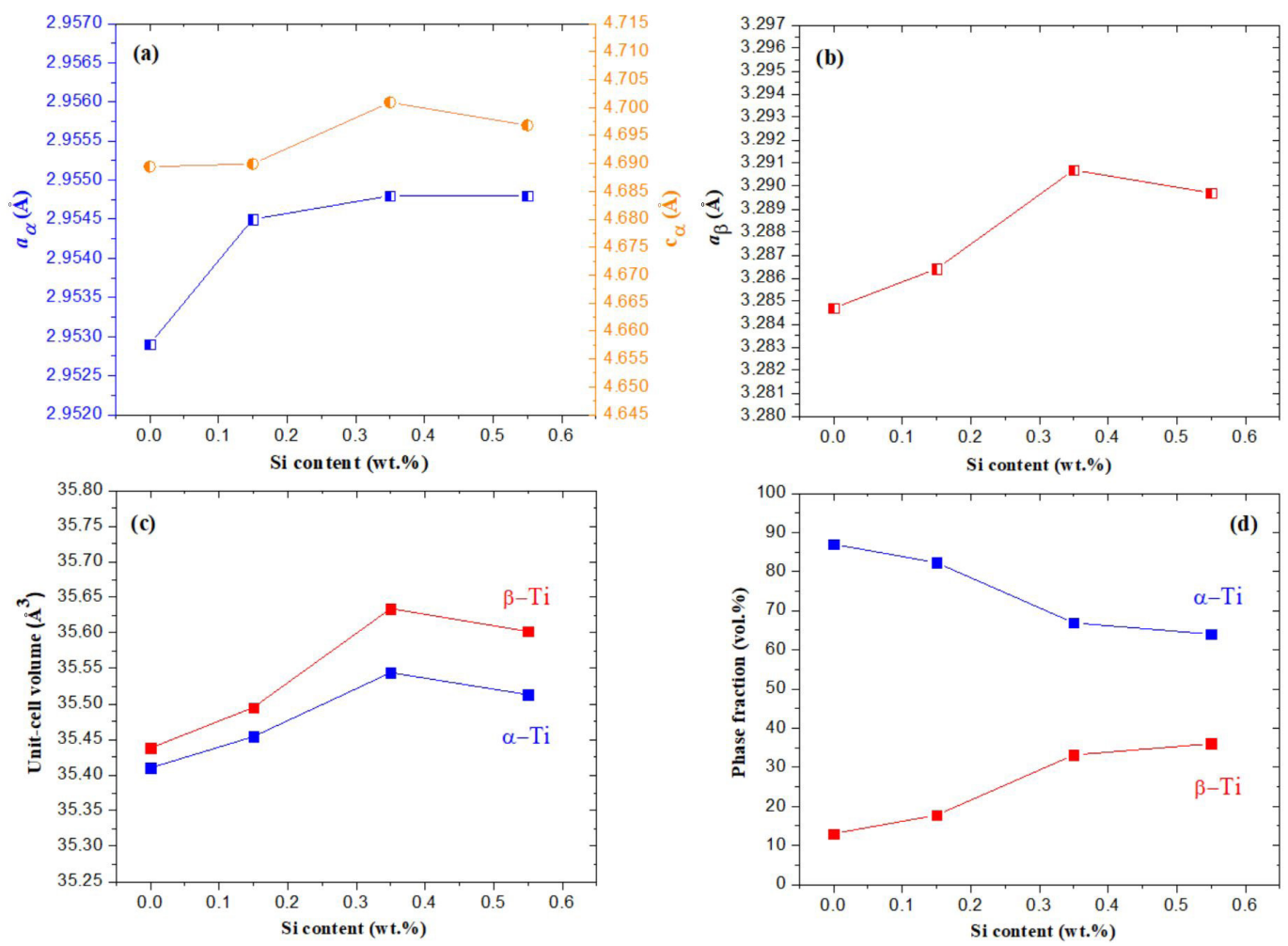

Figure 3. Variation of lattice parameters (a, b), unit-cell volumes (c) and phase fractions (d) of $\alpha$ and $\beta$ as function of Si contents recorded for furnace-cooled Ti-15Nb-xSi samples.

triggered structural changes in the Ti- $15 \mathrm{Nb}$ sample, considering the concentrations added.

The low Si concentrations used in this study minimize the risk of forming the intermetallic phases that are observed in the Ti-Si diagram ${ }^{34}$. The $\mathrm{Ti}_{3} \mathrm{Si}$ phase resulting from the eutectoid decomposition $\beta \rightarrow \alpha+\mathrm{Ti}_{3}$ Si would be the most likely precipitation to occur. However, it is worth noting that the addition of $\beta$-stabilizing elements, such as $\mathrm{Nb}$, can make this decomposition reaction slower, even during $\mathrm{FC}$, and this is more likely to occur at higher concentrations ${ }^{35}$. It is noted that, when solution-treating Ti-15Nb-xSi alloys at $1000^{\circ} \mathrm{C}$, the $\beta$-Ti field is narrow, and the continuous increase in $\mathrm{Nb}$ content gradually reduces the solubility of $\mathrm{Si}$ in the $\beta$-Ti phase ${ }^{36}$. According to Tavares et al. ${ }^{25}$, for $35 \mathrm{wt} . \% \mathrm{Nb}$, the solubility of $\mathrm{Si}$ in $\beta$-Ti phase was reached at $0.35 \mathrm{wt} . \%$. However, at 0.55 wt. $\% \mathrm{Si},(\mathrm{Ti}, \mathrm{Nb})_{3} \mathrm{Si}$ particles were observed because the solution treatment of this alloy occurred in the biphasic field $\beta-\mathrm{Ti}+(\mathrm{Ti}, \mathrm{Nb})_{3} \mathrm{Si}$. Comparable results were obtained by Masumoto et al. ${ }^{37}$, who worked with Ti-37.98Nb-1.71Al-(0.18, 0.29, 0.41, 0.47, and 0.53)Si alloys (wt.\%). These authors identified $(\mathrm{Ti}, \mathrm{Nb})_{3} \mathrm{Si}$ particles of approximately $200 \mathrm{~nm}$ in alloys containing $>0.41 \mathrm{wt} . \%$ $\mathrm{Si}$, which formed during solution treatment at $1000^{\circ} \mathrm{C}$ for $30 \mathrm{~min}$. Another study, with a lower concentration of $\mathrm{Nb}$, was conducted by Shevchenko et al. ${ }^{38}$, who investigated Ti-18Nb-xSi alloys with $0.6-1.2$ wt.\% Si quenched at temperatures from $800-1200^{\circ} \mathrm{C}$. ( $\left.\mathrm{Ti}, \mathrm{Nb}\right)_{3} \mathrm{Si}$ particles were observed in all alloys, and the number present increased as $\mathrm{Si}$ concentration increased. Particles in the Ti-18Nb-1.2Si alloy quenched from $1000^{\circ} \mathrm{C}$ exhibit an oval shape with cross-sectional size from $0.2-0.3 \mu \mathrm{m}$. It is worth noting that the heating processes at these temperatures were carried out in as-cast condition and pre-existing $(\mathrm{Ti}, \mathrm{Nb})_{3} \mathrm{Si}$ particles were not dissolved at temperatures $\leq 1000{ }^{\circ} \mathrm{C}$. The lower concentration of $\mathrm{Nb}, 15 \mathrm{wt} \%$, in this study increases the solubility of $\mathrm{Si}$ in the $\beta$-Ti phase and this is verified by the $1000^{\circ} \mathrm{C}$ isotherm of the $\mathrm{Ti}-\mathrm{Nb}-\mathrm{Si}$ system $^{36}$, where all compositions studied are within the $\beta$-Ti field.

To validate the argument above, SEM images of Ti$15 \mathrm{Nb}-(0.15 ; 0.35 ; 0.55) \mathrm{Si}$ samples, and their corresponding $\mathrm{Si}$ distribution maps were obtained by EDS (Figure 4). The Ti, $\mathrm{Nb}$, and Si composition of the samples was also determined, as shown in Table 2. Figure 4d-f shows homogeneous $\mathrm{Si}$ distribution at concentrations close to their nominal compositions (Table 2). This outcome indicates that there was no precipitation of Si-rich phase in the alloys. Therefore, the absence of precipitate in the images shown in Figure 4 is consistent with these observations.

SEM micrographs of Ti-15Nb-xSi samples heat-treated at $1000^{\circ} \mathrm{C}$ for $1 \mathrm{~h}$ and quenched in water resulted in the acicular martensitic structures shown in Figure 5. The Ti-15Nb sample has relatively thick and long primary martensite plates that become thinner as Si content increases. This morphological aspect is also observed when $\mathrm{Nb}$ content increases in $\mathrm{Ti}-\mathrm{Nb}$ alloys ${ }^{39}$. The optical micrographs displayed in the upper right corner of Figure 5a-d show that an increase in Si content results in a decrease in alloy grain size, as observed under FC conditions. The Si concentrations and their resulting mean grain sizes were $0 \%, 0.15 \%, 0.35 \%$, and $0.55 \%$, and $952 \pm 130 \mu \mathrm{m}, 724 \pm 171 \mu \mathrm{m}, 572 \pm 139 \mu \mathrm{m}$, and $376 \pm 92 \mu \mathrm{m}$, 
respectively. This effect is stronger in Ti-35Nb-xSi alloys, where $\beta$ phase retention is observed ${ }^{25}$, particularly in $0.55 \%$ $\mathrm{Si}$ due to the formation of $(\mathrm{Ti}, \mathrm{Nb})_{3} \mathrm{Si}$ particles, which were

Table 2. Compositions of furnace-cooled Ti-15Nb-xSi samples based on EDS

\begin{tabular}{cccc}
\hline \multirow{2}{*}{$\begin{array}{c}\text { Nominal content } \\
\text { (wt.\%) }\end{array}$} & \multicolumn{3}{c}{ EDS-obtained compositions (wt.\%) } \\
\cline { 2 - 4 } & $\mathrm{Ti}$ & $\mathrm{Nb}$ & $\mathrm{Si}$ \\
\hline Ti-15Nb-0.15Si & 85.4 & 14.4 & 0.2 \\
\hline Ti-15Nb-0.35Si & 85.5 & 14.2 & 0.3 \\
\hline Ti-15Nb-0.55Si & 85.4 & 14.1 & 0.5 \\
\hline
\end{tabular}

mostly located at the grain boundaries thereby preventing their growth ${ }^{40}$ and enhancing the refining effect.

Analysis of the XRD pattern shows that martensitic $\alpha$ ", with spatial group $\mathrm{Cmcm}$, was the only phase formed in water-quenched Ti-15Nb-XSi samples (Figure 6). This is consistent with the study by Bönisch et al. ${ }^{41}$, who determined that the transition from $\alpha$ ' to $\alpha$ " takes place at a concentration of $13.85 \mathrm{wt} . \% \mathrm{Nb}$. The Ti- $15 \mathrm{Nb}$ sample showed two values

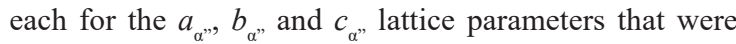
identified by the Rietveld method, as shown in Figure 6 and Table 3. Based on Bönisch et al. ${ }^{41}$, dimensions of unit cell $\alpha$ " are significantly influenced by $\mathrm{Nb}$ concentration.
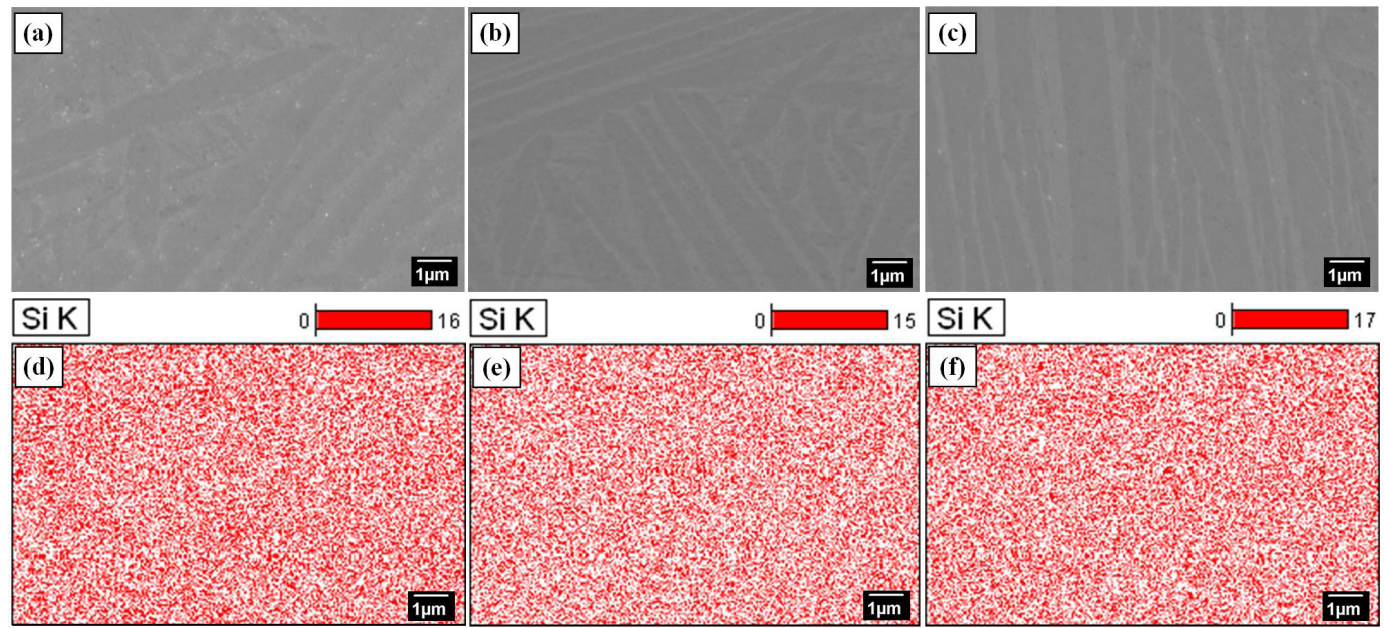

Figure 4. SEM/SEI images of FC Ti-15Nb-xSi samples with $\mathrm{x}=0.15(\mathrm{a}), \mathrm{x}=0.35$ (b) and $\mathrm{x}=0.55 \mathrm{Si}(\mathrm{c})$ and EDS mapping of Si (d-f), respectively.
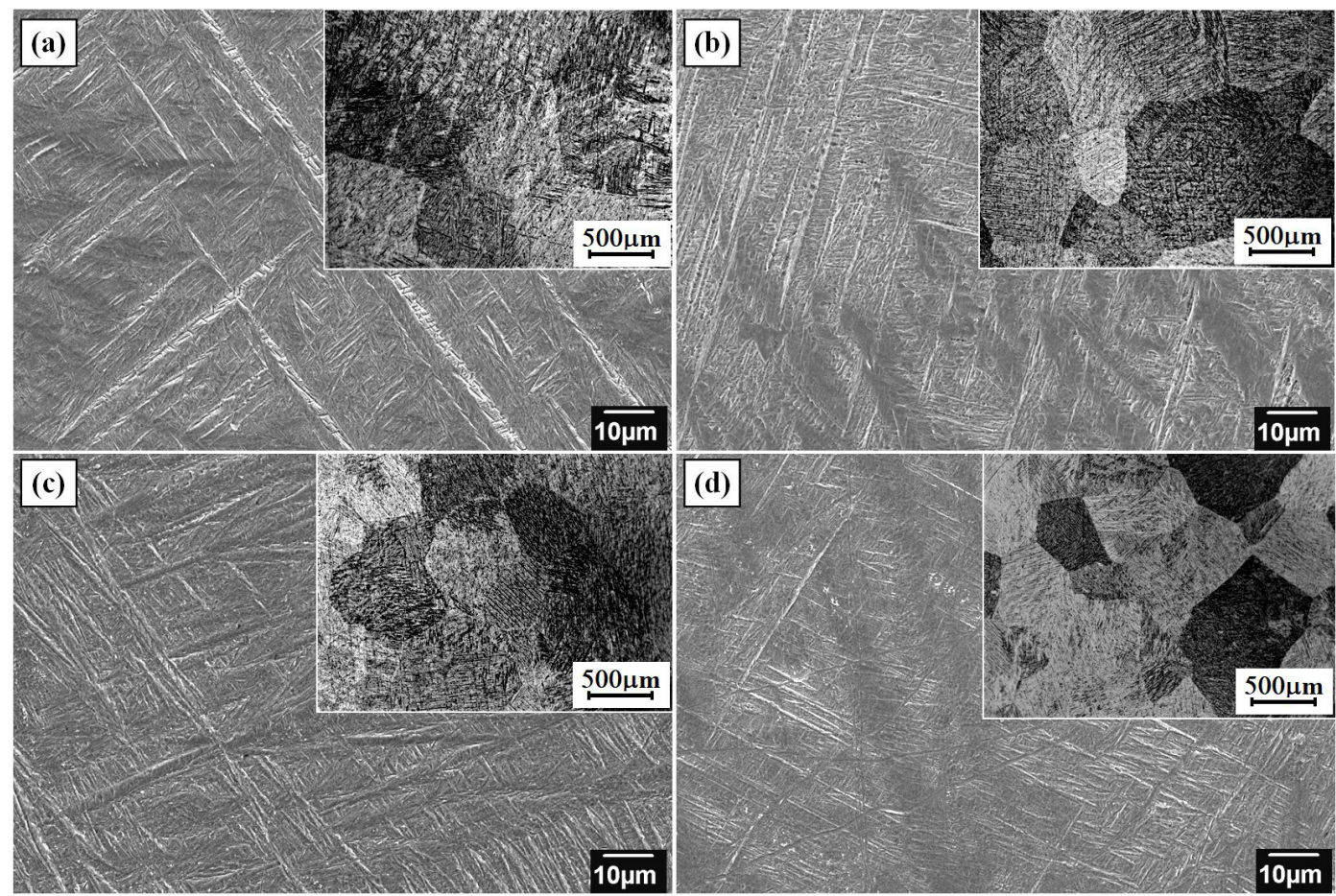

Figure 5. SEM micrographs of WQ samples: (a) Ti-15Nb, (b) Ti-15Nb-0.15Si, (c) Ti-15Nb-0.35Si, (d) Ti-15Nb-0.55Si. Inserts (a-d) present $\mathrm{OM}$ micrographs under lower magnifications. 

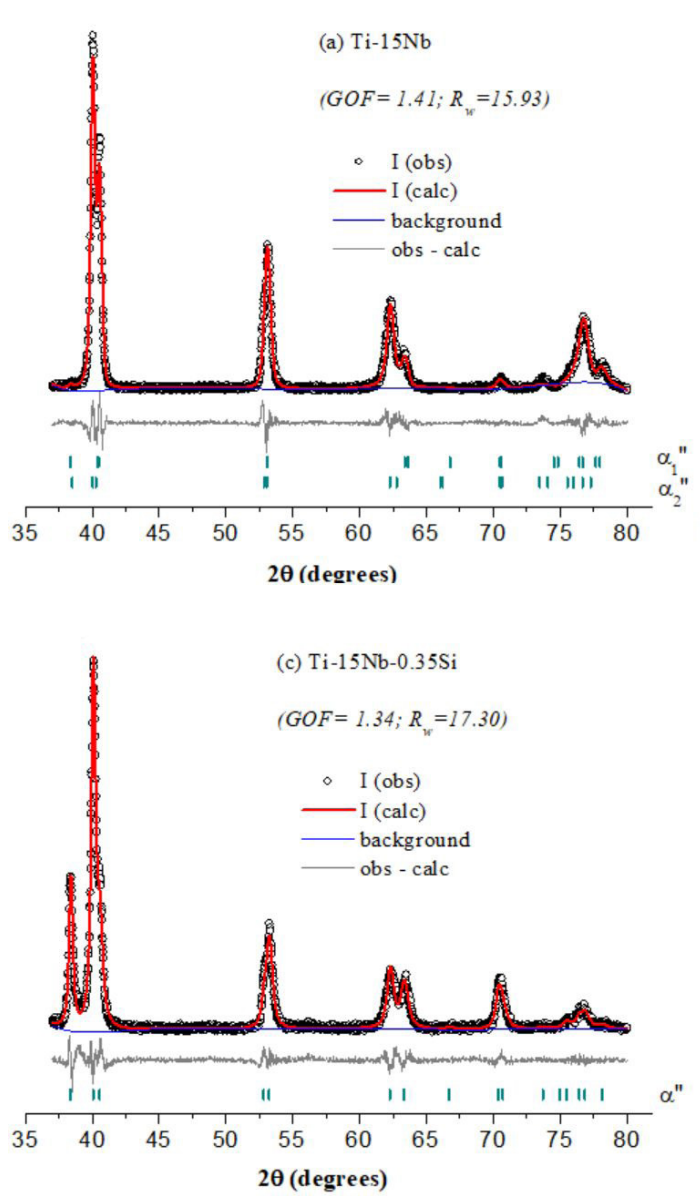
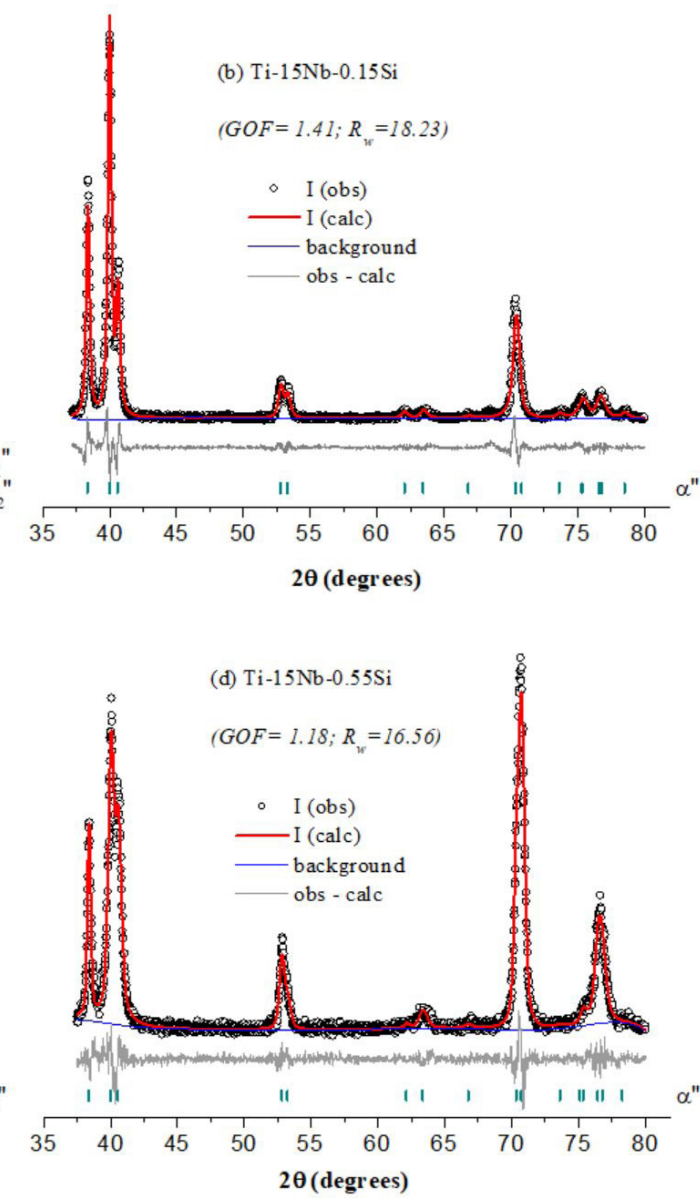

Figure 6. Observed $(\circ)$ and calculated (solid red line) XRD patterns recorded for WQ Ti-15Nb-xSi samples. The difference (solid grey line) is shown at the bottom of the image and Bragg reflections are indicated by vertical marks.

Table 3. Values of lattice parameters and volume fractions of the $\alpha$ " phase recorded for all observable reflections of water-quenched Ti-15Nb-xSi samples.

\begin{tabular}{lccccc}
\hline \multirow{2}{*}{$\begin{array}{c}\text { Nominal content } \\
(\text { wt. } \%)\end{array}$} & & \multicolumn{3}{c}{ Lattice parameter $(\AA)$} & \multirow{2}{*}{ Volume fraction } \\
\cline { 3 - 5 } & & $\mathrm{a}_{\alpha^{\prime \prime}}$ & $\mathrm{b}_{\alpha^{\prime \prime}}$ & $\mathrm{c}_{\alpha^{\prime \prime}}$ & \\
\hline \multirow{2}{*}{ Ti-15Nb } & $\left(\alpha_{1}{ }^{\prime \prime}\right)$ & 2.92952 & 5.09708 & 4.71056 & 0.685 \\
\hline & $\left(\alpha_{2}{ }^{\prime \prime}\right)$ & 2.98719 & 5.12340 & 4.68995 & 0.315 \\
\hline Ti-15Nb-0.15Si & & 2.99012 & 5.04406 & 4.69545 & 1.000 \\
\hline Ti-15Nb-0.35Si & & 2.98606 & 5.06942 & 4.70482 & 1.000 \\
\hline Ti-15Nb-0.55Si & & 2.99021 & 5.06172 & 4.70321 & 1.000 \\
\hline
\end{tabular}

It is important to note that the above authors investigated Ti-(9.1-39.3wt.\%)Nb alloys homogenized at $1000^{\circ} \mathrm{C}$ for $24 \mathrm{~h}$ under WQ. This indicates that the treatment time of $8 \mathrm{~h}$ at $1000{ }^{\circ} \mathrm{C}$ in the $\beta$ field adopted in the current study was not long enough for $\mathrm{Nb}$ to become evenly distributed in the sample, and WQ allowed this condition to remain unchanged. The same result was not observed in the samples with $\mathrm{Si}$ (Table 3), which had only one value for each parameter of the $\alpha$ " unit cell. This conforms with previous studies showing that substitutional atoms often diffuse faster along grain boundaries than through the crystal lattice at temperatures considerably below the melting point ${ }^{42}$. As already mentioned, $\mathrm{Si}$-stimulated grain refining required a larger total grain boundary area to increase the chances of achieving better $\mathrm{Nb}$ diffusion in $\beta$-Ti, because the $\mathrm{Nb}\left(D_{N b}\right)$ diffusion coefficient is slightly lower than the self-diffusion $\left(D_{T i}\right)$ coefficient within a wide range of temperatures ${ }^{43}$. On the other hand, it was observed that $D_{S i}$ is significantly higher than $D_{T i}$; this outcome was attributed to the prevailing effect of atom size on the diffusion of elements in $\beta-\mathrm{Ti}^{44}$. In this case, there is a large difference between the atomic radii of $\mathrm{Ti}(1.44 \AA)$ and $\mathrm{Si}(1.18 \AA)$.

The structural parameters of $\alpha$ " for water-quenched Ti-15Nb-xSi samples as a function of Si concentration are presented in Figure 7. The values recorded for the Ti-15Nb sample were obtained using the $\alpha_{1}$ " and $\alpha_{2}$ " lattice parameters and their respective volume fractions (Table 3 ), and therefore, in this case, they refer to the weighted average values. 

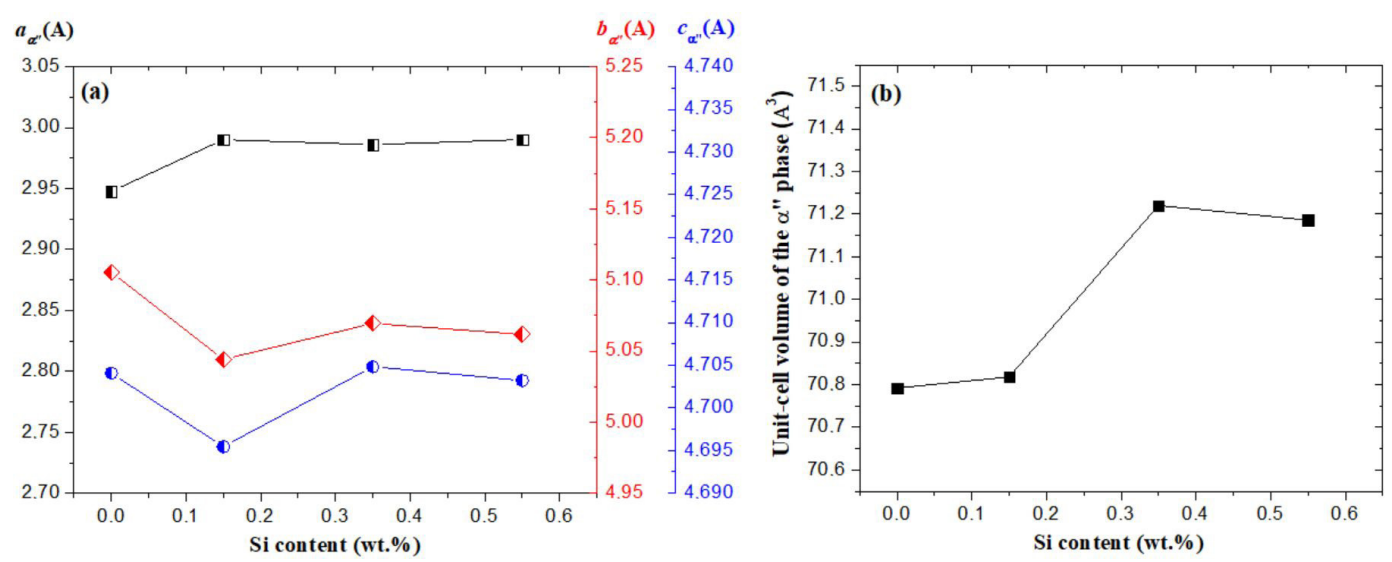

Figure 7. Variation of the lattice parameters (a) and unit-cell volume (b) of the $\alpha$ " phase as a function of Si content for WQ Ti-15Nb-xSi samples.

Significant changes in lattice parameters were observed in the $0.15 \%$ Si sample, where $a_{\alpha \text {, }}$ increased as $b_{\alpha \text {, }}$ and $c_{\alpha \text {, }}$ decreased (Figure 7a), although the unit cell volume included a value close to that recorded for the sample without Si (Figure 7b). Changes in the lattice parameters that result in a significant volume increase were only observed from $0.35 \% \mathrm{Si}$, given the increased $b_{\alpha, \text {, }}$ and $c_{\alpha \text { " }}$ parameters, whereas $a_{\alpha^{\prime \prime}}$ remained almost unchanged. The same behavior for the $a_{\alpha \text { " }}$ parameter was also observed in Ti-18Nb-(0.6-1.2)Si alloys quenched from $1100^{\circ} \mathrm{C}$ when the Si content had increased, although $c_{\alpha}$, and $b_{\alpha,}$, had significantly decreased ${ }^{38}$.

\subsection{Compositional influence on elastic modulus}

Figure 8 shows the effect on the elastic modulus of adding $\mathrm{Si}$ to Ti-15Nb-xSi samples under FC and WQ conditions. Comparing the two cooling conditions, higher values are observed for FC than WQ, because the FC samples mostly comprise $\alpha$ phase (Figure 2), whereas the WQ samples are formed by martensitic $\alpha$ " phase (Figure 6). This finding is consistent with the association between phases and the elastic moduli reported by Lee et al. ${ }^{45}$ in the Ti-Nb system, which are given as follows: $\omega>\alpha>\alpha$ ' $>\alpha$ " $>\beta$.

The Ti-15Nb sample recorded an E value of $98 \pm 1 \mathrm{GPa}$ under FC condition, which was consistent with data previously reported by Hon et al. ${ }^{19}$. The elastic modulus decreased and reached lower values from $\mathrm{Si}$ concentrations of $0.35 \%$, where $\mathrm{E}=90 \pm 2 \mathrm{GPa}$. The profile of this curve is a result of the increase in $\beta$ volume fraction with the addition of $\mathrm{Si}$; the most significant increase is from $0.15 \% \mathrm{Si}(17.7$ vol. $\% \beta)$ to $0.35 \%$ $\mathrm{Si}(31$ vol.\% $\beta$ ) (Figure 3d). Here, it is important to mention that $\beta$ presents the lowest elastic modulus among all stable and metastable phases ${ }^{45}$. Additionally, it is worth highlighting that in these Si concentrations, the $a_{\beta}$ parameter goes from $3.2864 \AA$ in $0.15 \%$ Si to $3.2907 \AA$ in $0.35 \%$ Si (Figure $3 b$ ). This significant increase in the network parameter of $\beta$-Ti in $0.35 \% \mathrm{Si}$ leads to a greater drop in the elastic modulus, because this property is determined by the bond strength between the atoms, which in turn is not only related to the crystalline structure, but also to the interatomic distances ${ }^{46}$.

The Ti-15Nb sample recorded an elastic modulus of $68.1 \pm 0.4 \mathrm{GPa}$ under WQ condition. This value accords with data reported by Ozaki et al. ${ }^{11}$. The curve profile is

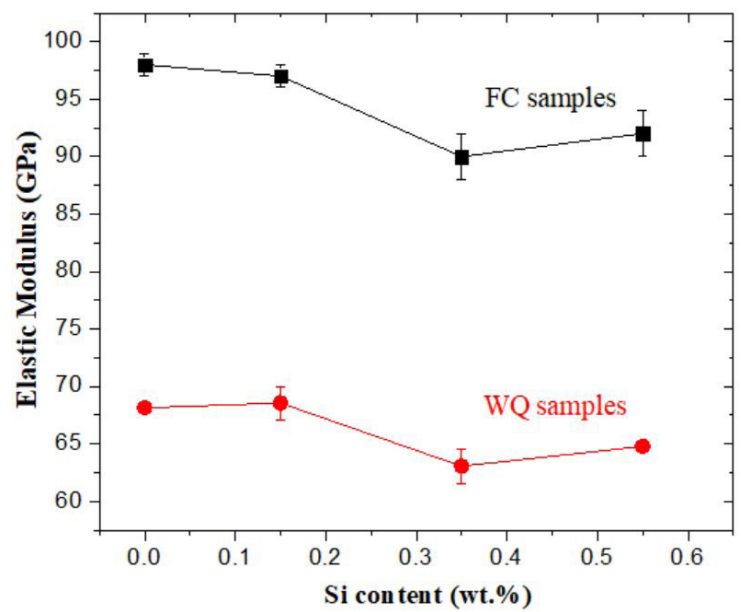

Figure 8. Elastic modulus of solution-treated samples as a function of Si content. FC: furnace-cooled; and WQ: water-quenched.

similar to that of the FC condition, in which the lowest elastic modulus of $63.1 \pm 1.5 \mathrm{GPa}$ was observed in the $0.35 \% \mathrm{Si}$ sample. As previously discussed, only the martensitic $\alpha$ " phase was identified in these samples (Figure 6). Therefore, the reduction is associated with the effect of $\mathrm{Si}$ on the orthorhombic structure, i.e., its increased unit cell volume. This effectively takes place from $0.35 \% \mathrm{Si}$, as shown in Figure $7 \mathrm{~b}$, as a result of the increase in $b_{\alpha \text {, }}$ and $c_{\alpha \text { " }}$ parameters, showing that $\mathrm{Si}$ is capable of contributing to bond strength reduction between the atoms, which is responsible for the elastic modulus performance ${ }^{46}$.

\subsection{Compositional influence on hardness}

Hardness values as a function of $\mathrm{Si}$ concentration for Ti-15Nb-xSi samples cooled in FC and WQ conditions are shown in Figure 9. The increase in Si content has assisted the increase in hardness of samples under both conditions. The variation in elastic modulus and hardness in $\beta$-type titanium alloys usually follow the same trend because most of these studies are on alloys with high concentrations of $\beta$-stabilizing elements, where the precipitation of $\omega$ on the $\beta$ matrix is frequently observed. It is noteworthy that $\omega$ phase exhibits 


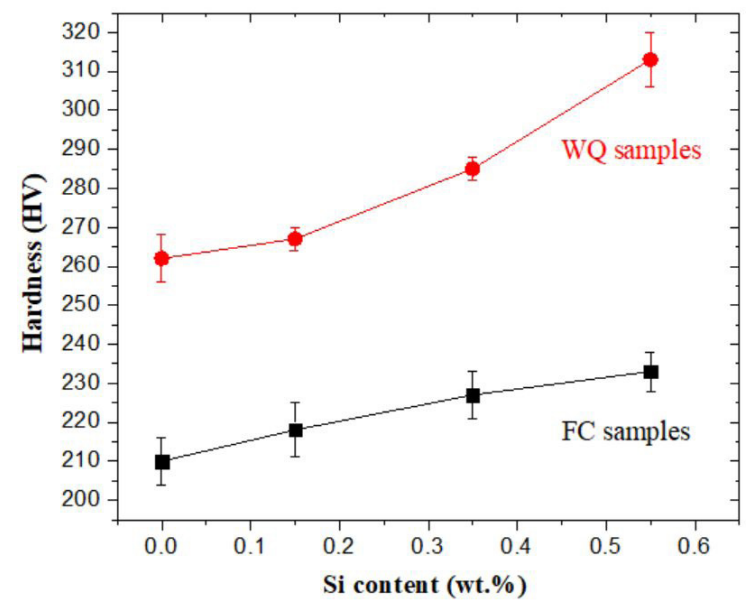

Figure 9. Hardness of solution-treated samples as a function of $\mathrm{Si}$ content. FC: furnace-cooled; and WQ: water-quenched.

the highest elastic modulus among all phases in titanium alloys $^{46,47}$, as well as playing an important role in increasing hardness ${ }^{45,46}$. Therefore, its presence strongly influences the hardness and elastic modulus profiles of these alloys.

Increasing $\mathrm{Si}$ concentration in Ti-35Nb-xSi alloys, investigated by Tavares et $\mathrm{al}^{25}$, was associated with a decrease in $\omega$ precipitate density on the $\beta$ matrix, because Si prevents its formation, resulting in an elastic modulus decrease. However, this was not shown for hardness because $\mathrm{Si}$ causes distortions in the CCC network ( $\beta$-Ti) which becomes progressively larger with increasing concentration. Its strong solid-solution-strengthening effect is due to the significant difference between the atomic radii of $\mathrm{Ti}(1.44 \AA)$ and $\mathrm{Si}$ $(1.18 \AA)^{23}$. A similar effect on hardness with the addition of $\mathrm{Si}$ is also seen in other Ti alloys ${ }^{48-50}$, as in this study.

Furthermore, $(\mathrm{Ti}, \mathrm{Nb})_{3} \mathrm{Si}$ particles were not observed in alloys with the addition of $\mathrm{Si}$, as shown in Figure 4. If $(\mathrm{Ti}, \mathrm{Nb})_{3} \mathrm{Si}$ particles were present in Ti-15Nb-xSi alloys, these would be coarse and incoherent with the matrix, as seen in Ti-Nb-Al-Si alloys with Si concentration $>0.41$ wt. $\%{ }^{37}$. It is important to note that while the solution temperature was the same in both situations $\left(1000^{\circ} \mathrm{C}\right)$, the time was $30 \mathrm{~min}$ for Ti-Nb-Al-Si alloys, but $1 \mathrm{~h}$ for the alloys investigated in this study, which would stimulate their increase further. This suggests that if $(\mathrm{Ti}, \mathrm{Nb})_{3} \mathrm{Si}$ particles were formed, their effect on the hardness would not be so significant on Ti-15Nb-xSi alloys, as the results obtained by Shevchenko et al. ${ }^{38}$ indicate that for Ti-18Nb-(0.6-1.2)Si alloys quenched from $1000^{\circ} \mathrm{C}$ resulted in hardness values from approximately $15.5 \mathrm{HRC}$ (Ti-18Nb) to $23.5 \mathrm{HRC}$ (Ti-18Nb-1.2Si). Moreover, according to these authors, the hardness values gradually increase with the addition of higher concentrations of Si due to the more intense saturation of the solid solution. However, as the amount of $(\mathrm{Ti}, \mathrm{Nb})_{3} \mathrm{Si}$ particles increases, there is a depletion of silicon in the solid solution, and the influence of the solid-solution hardening is weakened.

Figure 9 shows that the highest hardness values were observed under WQ conditions with values ranging from $262 \pm 6 \mathrm{HV}(\mathrm{Ti}-15 \mathrm{Nb})$ to $313 \pm 7 \mathrm{HV}$ (Ti-15Nb-0.55Si), whereas under FC conditions the values ranged from $210 \pm 6 \mathrm{HV}$ to $233 \pm 5 \mathrm{HV}$. According to Lee et al. ${ }^{45}$, the association between the phases and the hardness of Ti-Nb is $\omega>\alpha^{\prime}>\alpha$ " $>\beta>\alpha$; this behavior is attributable to the microstructures of WQ samples, which are only composed of a martensitic $\alpha$ " phase. According to the association established by Lee et al..$^{45}$ the bcc structure $(\beta$-Ti) contributes more significantly to hardness than the hcp structure $(\alpha-\mathrm{Ti})$, which must be related to the fact that $\beta$ phase is richer in $\beta$-stabilizing elements than $\alpha$. This finding reinforces the ascending profile of the FC sample curve, because the $\beta$ volume fraction increases as Si content increases (Figure 3d).

\section{Conclusions}

This study investigated the effect of silicon on the microstructures and properties of Ti-15Nb-xSi alloys under FC and WQ conditions. The study verified that Si acts as $\beta$-stabilizing element because the $\beta$ volume fraction increased from $13 \%$ to $36 \%$ in FC samples, as the concentration of added $\mathrm{Si}$ varied from 0 to $0.55 \mathrm{wt} . \%$. The effect of grain refining was also observed in WQ samples with increasing $\mathrm{Si}$ content. The elastic modulus decreased as Si content increased, most significantly in the sample with $0.35 \mathrm{wt} . \%$, which recorded $90 \pm 2 \mathrm{GPa}$ under FC condition, due to the increased $\beta$ volume fraction associated with the increase in its unit cell, and $63.1 \pm 1.5 \mathrm{GPa}$ under WQ condition as a consequence of increased $\alpha$ " unit cell volume. Hardness values were higher due to increased $\mathrm{Si}$ concentrations under both conditions, which can be attributed to its strong solid-solution-strengthening effect. This increase was more pronounced in WQ samples, due to the orthorhombic structure hardness of $\alpha$ ", which reached $262 \pm 6 \mathrm{HV}$ in Ti-15Nb and $313 \pm 7 \mathrm{HV}$ in Ti-15Nb-0.55Si.

\section{Acknowledgments}

We are grateful to $\mathrm{CNPq}$ for the financial support and to the Brazilian Metallurgy and Mining Company (CBMM) for the supply of $\mathrm{Nb}$. We also express our appreciation to Professor Rubens Caram for making the Physical Metallurgy Laboratory (LABMET/ FEM/ UNICAMP) available for the chemical analyses of the alloys.

\section{References}

1. Bahl S, Suwas S, Chatterjee K. Comprehensive review on alloy design, processing, and performance of $\beta$ Titanium alloys as biomedical materials. Int Mater Rev. 2021;66(2):114-39. http:// dx.doi.org/10.1080/09506608.2020.1735829.

2. He G, Hagiwara M. Ti alloy design strategy for biomedical applications. Mater Sci Eng C. 2006;26(1):14-9. http://dx.doi. org/10.1016/j.msec.2005.03.007.

3. Atapour M, Pilchak AL, Frankel GS, Williams JC. Corrosion behavior of $\beta$ titanium alloys for biomedical applications. Mater Sci Eng C. 2011;31(5):885-91. http://dx.doi.org/10.1016/j. msec.2011.02.005.

4. Surmeneva MA, Koptyug A, Khrapov D, Ivanov YF, Mishurova T, Evsevleev $\mathrm{S}$, et al. In situ synthesis of a binary $\mathrm{Ti}-10 \mathrm{at} \% \mathrm{Nb}$ alloy by electron beam melting using a mixture of elemental niobium and titanium powders. J Mater Process Technol. 2020;282:116646. http://dx.doi.org/10.1016/j.jmatprotec.2020.116646.

5. Fikeni L, Annan KA, Mutombo K, Machaka R. Effect of Nb content on the microstructure and mechanical properties of binary Ti-Nb alloys. Mater Today Proc. 2021;38:913-7. http:// dx.doi.org/10.1016/j.matpr.2020.05.315. 
6. Vishnu DSM, Sure J, Liu Y, Kumar RV, Schwandt C. Electrochemical synthesis of porous $\mathrm{Ti}-\mathrm{Nb}$ alloys for biomedical applications. Mater Sci Eng C. 2019;96:466-78. http://dx.doi.org/10.1016/j. msec.2018.11.025.

7. Karre R, Kodli BK, Rajendran A, J N, Pattanayak DK, Ameyama $\mathrm{K}$, et al. Comparative study on Ti-Nb binary alloys fabricated through spark plasma sintering and conventional $\mathrm{P} / \mathrm{M}$ routes for biomedical application. Mater Sci Eng C. 2019;94:619-27. http://dx.doi.org/10.1016/j.msec.2018.10.006.

8. Zhang Y, Sun D, Cheng J, Tsoi JKH, Chen J. Mechanical and biological properties of Ti- $(0-25 \mathrm{wt} \%) \mathrm{Nb}$ alloys for biomedical implants application. Regen Biomater. 2020;7(1):119-27. http:// dx.doi.org/10.1093/rb/rbz042.

9. Matsuno H. Biocompatibility and osteogenesis of refractory metal implants, titanium, hafnium, niobium, tantalum and rhenium. Biomaterials. 2001;22(11):1253-62. http://dx.doi. org/10.1016/S0142-9612(00)00275-1.

10. Mamoun F, Omar A, Mohamed L, Leila D, Iost A. Comparative study on tribological behavior of Ti-6Al-7Nb and SS AISI316L alloys, for total hip prosthesis. In: The Minerals, Metals \& Materials Society - TMS, editor. TMS 2014: $143^{\text {rd }}$ Annual Meeting \& Exhibition; 2014; San Diego, California. Proceedings. Cham: Springer; 2014. p. 237-46. https://doi.org/10.1007/978-3-319-48237-8_32.

11. Ozaki T, Matsumoto H, Watanabe S, Hanada S. Beta Ti alloys with low Young's modulus. Mater Trans. 2004;45(8):2776-9. http://dx.doi.org/10.2320/matertrans.45.2776.

12. Kuroda PAB, Silva LM, Sousa KSJ, Donato TAG, Grandini CR. Preparation, structural, microstructural, mechanical, and cytotoxic characterization of Ti- $15 \mathrm{Nb}$ alloy for biomedical applications. Artif Organs. 2020;44(8):811-7. http://dx.doi. org/10.1111/aor.13624.

13. Fellah M, Hezil N, Touhami MZ, Obrosov A, Weiß S, Kashkarov $\mathrm{EB}$, et al. Enhanced structural and tribological performance of nanostructured $\mathrm{Ti}-15 \mathrm{Nb}$ Alloy for biomedical applications. Results in Physics. 2019;15:102767. http://dx.doi.org/10.1016/j. rinp.2019.102767.

14. Schulze C, Weinmann M, Schweigel C, Keßler O, Bader R. Mechanical properties of a newly additive manufactured implant material based on Ti-42Nb. Materials. 2018;11(1):124. http:// dx.doi.org/10.3390/ma11010124.

15. Markhoff J, Weinmann M, Schulze C, Bader R. Influence of different grained powders and pellets made of Niobium and Ti-42Nb on human cell viability. Mater Sci Eng C. 2017;73:75666. http://dx.doi.org/10.1016/j.msec.2016.12.098.

16. Bönisch M, Calin M, Van Humbeeck J, Skrotzki W, Eckert J. Factors influencing the elastic moduli, reversible strains and hysteresis loops in martensitic Ti-Nb alloys. Mater Sci Eng C. 2015;48:511-20. http://dx.doi.org/10.1016/j.msec.2014.12.048.

17. Guo Y, Georgarakis K, Yokoyama Y, Yavari AR. On the mechanical properties of TiNb based alloys. J Alloys Compd. 2013;571:25-30. http://dx.doi.org/10.1016/j.jallcom.2013.03.192.

18. Mantani Y, Kudou K. Effect of plastic deformation on material properties and martensite structures in $\mathrm{Ti}-\mathrm{Nb}$ alloys. J Alloys Compd. 2013;577:S448-52. http://dx.doi.org/10.1016/j. jallcom.2012.04.054.

19. Hon YH, Wang JY, Pan YN. Composition/phase structure and properties of Titanium-Niobium alloys. Mater Trans. 2003;44(11):2384-90. http://dx.doi.org/10.2320/matertrans.44.2384.

20. Zhang J, Sun F, Hao Y, Gozdecki N, Lebrun E, Vermaut P, et al. Influence of equiatomic $\mathrm{Zr} / \mathrm{Nb}$ substitution on superelastic behavior of Ti-Nb-Zr alloy. Mater Sci Eng A. 2013;563:78-85. http://dx.doi.org/10.1016/j.msea.2012.11.045.

21. Moraes PEL, Contieri RJ, Lopes ESN, Robin A, Caram R. Effects of $\mathrm{Sn}$ addition on the microstructure, mechanical properties and corrosion behavior of $\mathrm{Ti}-\mathrm{Nb}-\mathrm{Sn}$ alloys. Mater Charact. 2014;96:273-81. http://dx.doi.org/10.1016/j.matchar.2014.08.014.
22. Yang R, Rahman KM, Rakhymberdiyev AN, Dye D, Vorontsov VA. Mechanical behaviour of Ti-Nb-Hf alloys. Mater Sci Eng A. 2019;740-741:398-409. http://dx.doi.org/10.1016/j.msea.2018.10.019.

23. Zhang DC, Mao YF, Li YL, Li JJ, Yuan M, Lin JG. Effect of ternary alloying elements on microstructure and superelastictity of Ti-Nb alloys. Mater Sci Eng A. 2013;559:706-10. http:// dx.doi.org/10.1016/j.msea.2012.09.012.

24. Kim H-S, Kim W-Y, Lim S-H. Microstructure and elastic modulus of Ti-Nb-Si ternary alloys for biomedical applications. Scr Mater. 2006;54(5):887-91. http://dx.doi.org/10.1016/j. scriptamat.2005.11.001

25. Tavares AMG, Ramos WS, de Blas JCG, Lopes ESN, Caram R, Batista WW, et al. Influence of Si addition on the microstructure and mechanical properties of Ti-35Nb alloy for applications in orthopedic implants. J Mech Behav Biomed Mater. 2015;51:7487. http://dx.doi.org/10.1016/j.jmbbm.2015.06.035.

26. Tavares AMG, Fernandes BS, Souza SA, Batista WW, Cunha FGC, Landers R, et al. The addition of Si to the Ti-35Nb alloy and its effect on the corrosion resistance, when applied to biomedical materials. J Alloys Compd. 2014;591:91-9. http:// dx.doi.org/10.1016/j.jallcom.2013.12.183.

27. Wang W, Han J, Yang X, Li M, Wan P, Tan L, et al. Novel biocompatible magnesium alloys design with nutrient alloying elements $\mathrm{Si}, \mathrm{Ca}$ and $\mathrm{Sr}$ : structure and properties characterization. Mater Sci Eng B. 2016;214:26-36. http://dx.doi.org/10.1016/j. mseb.2016.08.005.

28. Toby BH, Von Dreele RB. GSAS-II: the genesis of a modern open-source all purpose crystallography software package. J Appl Cryst. 2013;46(2):544-9. http://dx.doi.org/10.1107/ S0021889813003531.

29. American Society for Testing and Materials - ASTM. ASTM B977/B977M-19: standard specification for titanium and titanium alloy ingots. West Conshohocken: ASTM International; 2019. https://dx.doi.org/10.1520/B0977_B0977M-19.

30. Ibrahim KM, Hussein AH, Abdelkawy M. Effect of Si-addition as a grain refiner on microstructure and properties of Ti-6Al-4V alloy. Trans Nonferrous Met Soc China. 2013;23(7):1863-74. http://dx.doi.org/10.1016/S1003-6326(13)62671-0.

31. Bermingham MJ, Mcdonald SD, Dargusch MS, StJohn DH The mechanism of grain refinement of titanium by silicon. Scr Mater. 2008;58(12):1050-3. http://dx.doi.org/10.1016/j. scriptamat.2008.01.041.

32. Barriobero-Vila P, Requena G, Buslaps T, Alfeld M, Boesenberg U. Role of element partitioning on the $\alpha-\beta$ phase transformation kinetics of a bi-modal Ti-6Al-6V-2Sn alloy during continuous heating. J Alloys Compd. 2015;626:330-9. http://dx.doi. org/10.1016/j.jallcom.2014.11.176.

33. Souza SA, Manicardi RB, Ferrandini PL, Afonso CRM, Ramirez AJ, Caram R. Effect of the addition of Ta on microstructure and properties of Ti-Nb alloys. J Alloys Compd. 2010;504(2):33040. http://dx.doi.org/10.1016/j.jallcom.2010.05.134.

34. Fiore M, Beneduce F No, Azevedo CRF. Assessment of the Ti-rich corner of the Ti-Si phase diagram: the recent dispute about the eutectoid reaction. Mater Res. 2016;19(4):942-53. http://dx.doi.org/10.1590/1980-5373-MR-2016-0157.

35. Narayanan GH, Archbold TF. Decomposition of the metastable $\beta$ phase in the all- $\beta$ alloy Ti-13V-11Cr-3Al. Metall Trans. 1970;1(8):2281-90. http://dx.doi.org/10.1007/BF02643446.

36. Xu H, Du Y, Chen H, He Y, Pan Z, Schuster JC, et al. Isothermal section at $1,000^{\circ} \mathrm{C}$ of the $\mathrm{Nb}-\mathrm{Ti}-\mathrm{Si}$ system. J Alloys Compd. 2005;394(1-2):235-9. http://dx.doi.org/10.1016/j. jallcom.2004.11.016.

37. Masumoto K, Horiuchi Y, Inamura T, Hosoda H, Wakashima K, Kim HY, et al. Effects of Si addition on superelastic properties of $\mathrm{Ti}-\mathrm{Nb}-\mathrm{Al}$ biomedical shape memory alloys. Mater Sci Eng A. 2006;438-440:835-8. http://dx.doi.org/10.1016/j. msea.2006.02.060 
38. Shevchenko OM, Kulak LD, Kuzmenko MM, Firstov SO. Formation of silicides and their influence on the structure and properties of cast alloys of the $\mathrm{Ti}-18 \mathrm{Nb}-x \mathrm{Si}$ system for biomedical purposes. Mater Sci. 2020;55(4):577-84. http:// dx.doi.org/10.1007/s11003-020-00341-0.

39. Banumathy S, Mandal RK, Singh AK. Structure of orthorhombic martensitic phase in binary $\mathrm{Ti}-\mathrm{Nb}$ alloys. J Appl Phys. 2009;106(9):093518. http://dx.doi.org/10.1063/1.3255966.

40. Ma Y, Yang S, Jin W, Wang Y, Wang C, Liu X. Microstructure, mechanical and shape memory properties of Ti-55Ta-XSi biomedical alloys. Trans Nonferrous Met Soc China. 2011;21(2):287-91. http://dx.doi.org/10.1016/S1003-6326(11)60711-5.

41. Bönisch M, Calin M, Giebeler L, Helth A, Gebert A, Skrotzki $\mathrm{W}$, et al. Composition-dependent magnitude of atomic shuffles in Ti-Nb martensites. J Appl Cryst. 2014;47(4):1374-9. http:// dx.doi.org/10.1107/S1600576714012576.

42. Balluffi RW. Grain boundary diffusion mechanisms in metals. J Electron Mater. 1992;21(4):527-53. http://dx.doi.org/10.1007/ BF02650011.

43. Nakajima H, Koiwa M. Diffusion in Titanium. ISIJ Int. 1991;31(8):757-66. http://dx.doi.org/10.2355/isijinternational.31.757.

44. Iijima $Y$, Lee $S-Y$, Hirano K-I. Diffusion of silicon, germanium and tin in $\beta$-titanium. Philos Mag A Phys Condens Matter Defects Mech Prop. 1993;68(5):901-14. http://dx.doi. org/10.1080/01418619308219375.
45. Lee CM, Ju CP, Chern Lin JH. Structure-property relationship of cast Ti-Nb alloys. J Oral Rehabil. 2002;29(4):314-22. http:// dx.doi.org/10.1046/j.1365-2842.2002.00825.x.

46. Zhou YL, Niinomi M, Akahori T. Decomposition of martensite $\alpha^{\prime \prime}$ during aging treatments and resulting mechanical properties of Ti-Ta alloys. Mater Sci Eng A. 2004;384(1-2):92-101. http:// dx.doi.org/10.1016/j.msea.2004.05.084.

47. Matlakhova LA, Matlakhov AN, Monteiro SN, Fedotov SG, Goncharenko BA. Properties and structural characteristics of Ti-Nb-Al alloys. Mater Sci Eng A. 2005;393(1-2):320-6. http:// dx.doi.org/10.1016/j.msea.2004.11.021.

48. Shimagami K, Ito T, Toda Y, Yumoto A, Yamabe-Mitarai Y. Effects of $\mathrm{Zr}$ and $\mathrm{Si}$ addition on high-temperature mechanical properties and microstructure in Ti-10Al-2Nb-based alloys. Mater Sci Eng A. 2019;756:46-53. http://dx.doi.org/10.1016/j. msea.2019.04.031.

49. Ding D, Zhang DC, Luo ZC, Tan CG, Zhang Y, Lin JG. Effects of $\mathrm{Si}$ addition on mechanical properties and superelasticity of $\mathrm{Ti}-7.5 \mathrm{Nb}-4 \mathrm{Mo}-2 \mathrm{Sn}$ shape memory alloy. Mater Des. 2014;61:146-9. http://dx.doi.org/10.1016/j.matdes.2014.04.043.

50. Wang X, Wang L, Wang QJ, Wu YD, Si JJ, Hui XD. Enhanced mechanical properties and structure stability induced by $\mathrm{Si}$ in Ti-8.5Al-1.5Mo alloys. Mater Sci Eng A. 2016;676:304-11. http://dx.doi.org/10.1016/j.msea.2016.09.009. 